\title{
Stakeholders' satisfaction as a key determinant of critical success factors in renewable energy projects
}

\author{
Rashid Maqbool ${ }^{1 *}$, Xiaomei Deng ${ }^{2^{*}}$ and Yahya Rashid ${ }^{3^{*}}$
}

\begin{abstract}
Renewable energy projects (REPs) are critical to providing a clean and sustainable environmental perspective alongside the economic prosperity of any country. Unfortunately, recent trends in renewable energy projects (REPs) are not positive enough regarding their successful completion within the budgeted cost, planned time, proposed quality, and other necessary constraints. Although the pertinent literature has discussed the critical success factors (CSFs) for such projects, their influencing mechanism with respect to the role of key stakeholders is still overlooked. This study recognizes several critical success factors (CSFs) and their influencing mechanisms onto renewable energy projects (REPs) in order to evaluate direct influences onto project success as well as indirect influences through stakeholders' satisfaction (SS) as mediation on the project success of small and medium-sized renewable energy projects (REPs) in Pakistan's energy sector. A sample of about 272 respondents working with renewable energy projects (REPs), including key stakeholders, has been collected to perform data analysis and draw inferences. A structural equation modeling (SEM) approach was used for data analysis and inference drawing. The results show that though there is a positive and direct association between critical success factors (CSFs) and project success, a partial mediating role of stakeholders' satisfaction (SS) between CSFs and project success was still determined. Hence, it was found that CSFs significantly contribute to renewable energy projects (REPS) through mediating influences of stakeholders' satisfaction (SS). The findings confirmed that stakeholders' satisfaction (SS) is a key determinant for critical success factors (CSFs) in renewable energy projects (REPS). Moreover, stakeholders' satisfaction (SS) emerged to be a crucial element for the completion of such projects. The empirical findings of this study might have a useful effect on academicians and the practitioners engaged with renewable energy projects (REPs).
\end{abstract}

Keywords: Critical success factors, Renewable energy projects, Stakeholders' satisfaction, Project success

\footnotetext{
*Correspondence: mrashid@tsinghua.edu.cn; dengxm@tsinghua.edu.cn; y_rashid@yahoo.com

'Department of Construction Management, Tsinghua University, Beijing, People's Republic of China

${ }^{2}$ Department of Construction Management, Tsinghua University, Beijing, People's Republic of China

${ }^{3}$ Department of Mechanical Engineering, Prince Sattam Bin Abdulaziz University, Al-Kharj, Kingdom of Saudi Arabia
}

(c) The Author(s). 2020 Open Access This article is licensed under a Creative Commons Attribution 4.0 International License, which permits use, sharing, adaptation, distribution and reproduction in any medium or format, as long as you give appropriate credit to the original author(s) and the source, provide a link to the Creative Commons licence, and indicate if changes were made. The images or other third party material in this article are included in the article's Creative Commons licence, unless indicated otherwise in a credit line to the material. If material is not included in the article's Creative Commons licence and your intended use is not permitted by statutory regulation or exceeds the permitted use, you will need to obtain permission directly from the copyright holder. To view a copy of this licence, visit http://creativecommons.org/licenses/by/4.0/ The Creative Commons Public Domain Dedication waiver (http://creativecommons.org/publicdomain/zero/1.0/) applies to the data made available in this article, unless otherwise stated in a credit line to the data. 


\section{Background}

Apart from the eradication of poverty in any country, the influence of energy is fierce for economic prosperity and development. Sustained energy supply is an utmost concern for every country in the world today. Succeeding in economic prosperity relies significantly on the extended accessibility of energy from sources that are cost-effective, convenient, and eco-friendly [1]. Safe future, global warming, and community hygienic environments are intimately connected with energy [2]. An overwhelming growth in population will lead to a continuously rising demand for energy, whose demand streams might only be met by economies using renewable energy projects (REPs). Moreover, these REPs might also assist lower-carbon economies to align with the Paris agreement.

Since 1987, the importance of sustainability has been highlighted and until now, insufficient action has been taken to achieve environmental sustainability [3]. Ongoing pollution, deterioration of the environment, declining of fresh water supply, and foremost, numerous natural mega-disasters, e.g., landslides, earthquakes, and typhoons, are happening all over the world. Due to this reason, we have tried to focus the world's attention on the urgent need for more research and practical steps in environmental issues dealing with the sustainable objectives of this study. It is increasingly clear that today scientists have to take steps to achieve sustainability for all aspects of the environment in order to overcome and control environmental disasters and to make sure that the world we live in can be sustained.

Renewable energy projects (REPs) play an imperative part in securing this world as well as its natural atmosphere, human beings, and environmental health, alongside framing modernization and fulfilling our needs without conceding the needs of the upcoming generations $[1,2]$. These days, we as human beings face the harmful effects of a worldwide temperature rise as well as environmental changes due to hasty and unrestrained industrial developments. The danger linked with climate change grows with each day. It is a fact that climate change is the utmost crucial matter currently challenging this globe. It is today well recognized that climate change is the major cause behind the severe downturn in agricultural production, serious water tension, expanding sea levels, and alarming hazards to human health, particularly in the developing areas of the world [4]. Hence, with the current study, we aim to address the need for high-performance renewable energy resources, as one of the imperative pillars for a sustainable environment of our society, and for the convey of our findings to scientists, regulation makers, environmentalists, decision-makers, students, politicians, officials from business, industry, NGOs, experts, and investigators who understand the significance of environmental sustainability while overcoming the after-effects of global warming and climate change.

Hence, the aim of this research is to determine several CSFs and their influencing mechanisms on REPs. First of all, the direct influences of CSFs onto the success of the project have been checked. The indirect influences are identified by measuring the mediating role of stakeholders' satisfaction (SS) in between the CSFs and the project success of small and medium-sized REPs in Pakistan's energy sector. Accordingly, inferences are drawn based on a statistical data analysis, and recommendations are suggested for practitioners working with REPs.

\section{Potential and progress of ongoing renewable energy projects (REPs) in Pakistan}

Despite being observably influenced and among the top ten "most-defenseless" nations on the planet, Pakistan continues the endeavor of a solution to its energy crises in fossil fuel $[5,6]$. Nevertheless, Pakistan is a nation favored with renewable energy (RE) sources, which can be exploited for power production. An ample amount of water, wind, and solar energy potentials are available in a land area of approximately $800,000 \mathrm{~km}^{2}$ [7]. There are also additional tremendous possibilities for biomass from animal dung and agriculture residues. Altogether, renewable energy projects (REPs) can possibly deliver abundant energy for the nation, which will eradicate the requirement of fossil fuel. For this segment, we provide a comprehensive view of accessible resources and potentials in the country of Pakistan.

Pakistan has huge potential to produce renewable energy through the successful use of biomass, solar and geothermal energy, wind power, and small hydropower plants. According to some reliable resources, Pakistan has a potential to provide renewable energy of $1600 \mathrm{GW}$ through solar energy projects [8], up to $44,000 \mathrm{MW}$ through wind power projects $[9,10], 13,900 \mathrm{GWh}$ through biomass projects [11], 100,000 MW through geothermal resources [12], and $100 \mathrm{GW}$ through small hydropower projects [13].

In spite of the enormous potential of renewable energy (RE) in Pakistan, many of such on-going projects are not generating their expected results. The failure of these projects to provide the planned operational performance is mainly due to multiple challenges such as lack of data and transparency, an unstable economy, corruption, political instability, financial constraints, and socio-cultural challenges; as distinct from those faced by their counterparts elsewhere. The list of Pakistan's renewable energy projects (REPs), which have been recently abandoned or delayed due to poor operational performance, is quite long [14]. Hence, there is an important research call to 
explore such aspects that can tackle these issues while helping policymakers in the country.

\section{Critical success factors in constructing renewable energy projects}

Projects in the construction industry are considered to be successful if completed within their scope, schedule, and budget constraints while ensuring the desired quality of the customers [15]. Renewable energy projects (REPs) are usually conducted in the complex environment where a lot of stakeholders and resources are involved. Thus, apart from the role of key stakeholders, success in the REPs relies on multiple CSFs. This section of the current research presents a comprehensive review of former empirical studies on the aspect of CSFs, which might hypothetically direct current research towards including influencing factors in the renewable energy projects (REPs). Previous empirical studies on CSFs, such as those carried out by Standish [16], Baccarini and Collins [17], Zhao et al. [18], Ika et al. [19], Xu et al. [20], Maqbool and Sudong [1], Maqbool [2], and Maqbool et al. [4], have been considered as follows.

According to Standish [16], the critical success factors (CSFs) for constructing projects include administrative backing, customer/client participation in the project, well-defined objectives, realistic expectations, and workable forecasting. In the study performed by Baccarini and Collins [17] with 150 participants of the Australian Project Management Institute (APMI), fifteen CSFs have been found indispensable for project success (PS), among which project know-how and a capable project team, determined as key factors for successful projects. The significance of this research is that it is based on a survey of diverse project types, for instance, construction, telecommunication, information technology (IT), education, and defense. However, about 45.3 proportion of survey respondents were part of the construction industry. Another significance of their study is that no considerable aberrations are observed in the data composed from the diverse industrial settings.

The empirical research conducted by Zhao et al. [18] has found CSFs be included in the BOT thermal and wind power/energy projects in China. The survey findings of their research have demonstrated that there are five categories of CSFs, which are project planning, project atmosphere, project cooperation, project suppliers, and project contractors.

The empirical study done by Ika et al. [19] investigated CSFs in the World Bank's sponsored projects, which amounted to a 2.7 proportion of energy-related projects. The research study based upon 147 diverse project areas, has recognized 5 groups of CSFs, namely training, design, coordination, monitoring, and organizational atmosphere. Xu et al. [20] have established several CSFs of energy performance contracting (EPC) required for the building energy efficiency retrofit (BEER) of hotel building projects carried out in China. Their study is based on a pragmatic approach, in which a mixed method of data collections is used, which also includes semistructured interviews for qualitative data research and a questionnaire survey for quantitative data research for the important participants of the construction projects. The outcomes of their research implement 21 success factors in the 6 major categories of critical success factors (CSFs). Their classifications include EPC funding for the project of hotel retrofit, execution of a sustainable construction plan, firm's processes, sustainable development (SD), and measurement and verification $(\mathrm{M} \& \mathrm{~V})$, external financial situation, and contractual procedure.

Alongside three important and recent studies by Maqbool and colleagues [1, 2, 4] conducted for Pakistani REPs contexts have also been considered in order to recognize the CSFs required for REPs.

In the first study, Maqbool and Sudong [1] have put a lot of work into the identification process of CSFs for constructing REPs in Pakistan. Moreover, they have also identified the significant success factors (SSFs) behind each critical success factor category. While using a systematic process, they have investigated the five "imperative" classes of CSFs required for the on-going REPs, namely communication factors (CF), team factors (TF), technical factors (Tech.F), organizational factors (OF), and environmental factors (EF). Moreover, the authors have succeeded in confirming a linkage of these categories with project success (PS) by using bivariate correlation analysis (BCA) and multiple linear regression analysis.

The second research by Maqbool et al. [4] is an extension of a previous study conducted by Maqbool and Sudong [1]. In this research, they have recognized a direct as well as an indirect linkage of CSFs with project success (PS). Their results confirm that all the CSFs groups have a positive and direct linkage to project success (PS), whereas the environmental factors (EF) belong to the only CSFs category, which also indirectly contributes to project success (PS). This has led the environmental factors (EF) to become the leading critical success factors (CSFs) category among other CSFs required in renewable energy projects (REPs).

The third and most important study conducted by Maqbool [2] has highlighted the influencing mechanisms of critical success factors onto the short-term success (efficiency) and long-term success (effectiveness) in renewable energy projects (REPs). Structural equation modeling (SEM) analysis was employed in the research to examine and prove the hypotheses. The outcome has demonstrated that although the efficiency (short-term success) and effectiveness (long-term success) of CSFs 
Table 1 Identification of factors influencing the renewable energy projects (REPs)

\begin{tabular}{|c|c|c|c|c|c|}
\hline Reference & $\begin{array}{l}\text { Communication } \\
\text { factors (CF) }\end{array}$ & Team factors (TF) & Technical factors (Tech.F) & $\begin{array}{l}\text { Organizational } \\
\text { factors (OF) }\end{array}$ & $\begin{array}{l}\text { Environmental } \\
\text { factors (EF) }\end{array}$ \\
\hline Zhao and Chen [21] & $\checkmark$ & $\checkmark$ & $\checkmark$ & & $\checkmark$ \\
\hline Kirchhoff et al. [22] & & & $\checkmark$ & & $\checkmark$ \\
\hline Maqbool and Sudong [1] & $\checkmark$ & $\checkmark$ & $\checkmark$ & $\checkmark$ & $\checkmark$ \\
\hline Maqbool [2] & $\checkmark$ & $\checkmark$ & $\checkmark$ & $\checkmark$ & $\checkmark$ \\
\hline Maqbool et al. [4] & $\checkmark$ & $\checkmark$ & $\checkmark$ & $\checkmark$ & $\checkmark$ \\
\hline Xu et al. [20] & $\checkmark$ & $\checkmark$ & $\checkmark$ & $\checkmark$ & $\checkmark$ \\
\hline Zhao et al. [18] & $\checkmark$ & $\checkmark$ & $\checkmark$ & $\checkmark$ & $\checkmark$ \\
\hline Liang et al. [23] & & $\checkmark$ & $\checkmark$ & $\checkmark$ & $\checkmark$ \\
\hline Zhao et al. [24] & $\checkmark$ & & $\checkmark$ & & $\checkmark$ \\
\hline Dong et al. [25] & & & & $\checkmark$ & $\checkmark$ \\
\hline Lin and Moubarak [26] & & $\checkmark$ & & & $\checkmark$ \\
\hline Young and Brans [27] & $\checkmark$ & $\checkmark$ & & $\checkmark$ & $\checkmark$ \\
\hline Carlisle et al. [28] & & & $\checkmark$ & & $\checkmark$ \\
\hline Zhao et al. [29] & $\checkmark$ & $\checkmark$ & $\checkmark$ & & $\checkmark$ \\
\hline Xavier et al. [30] & $\checkmark$ & & $\checkmark$ & & $\checkmark$ \\
\hline Ansari et al. [31] & $\checkmark$ & $\checkmark$ & $\checkmark$ & $\checkmark$ & $\checkmark$ \\
\hline Pantaleo et al. [32] & $\checkmark$ & & $\checkmark$ & $\checkmark$ & $\checkmark$ \\
\hline He et al. [33] & & & $\checkmark$ & $\checkmark$ & $\checkmark$ \\
\hline Goh et al. [34] & $\checkmark$ & & $\checkmark$ & & $\checkmark$ \\
\hline Zhao et al. [35] & $\checkmark$ & & $\checkmark$ & $\checkmark$ & $\checkmark$ \\
\hline Lam et al. [36] & $\checkmark$ & & $\checkmark$ & $\checkmark$ & $\checkmark$ \\
\hline Qi et al. [37] & & & $\checkmark$ & & $\checkmark$ \\
\hline Kaldellis et al. [38] & $\checkmark$ & & $\checkmark$ & & $\checkmark$ \\
\hline Wu et al. [39] & $\checkmark$ & & $\checkmark$ & $\checkmark$ & $\checkmark$ \\
\hline Total & 17 & 11 & 21 & 14 & 24 \\
\hline
\end{tabular}

are likewise mandatory in constructing renewable energy projects (REPs), the effectiveness (long-term success) in such kinds of projects is heavily relying on the efficiency (short-term success) of the CSFs of such REPs. Table 1 presents the most important reference studies with the suggested CSFs discussed for the REPs.

Despite the significant contributions of researches conducted by Maqbool and colleagues [1, 2, 4], none of their studies is focused on the stakeholders' satisfaction of renewable energy projects (REPs). Project completion is not the real success of such projects, the ultimate purpose is to attain the stakeholders' satisfaction of REPs. According to earlier studies, the findings of the literature are still inconclusive and cannot be generalized regarding the stakeholders' satisfaction and project success (PS) of REPs. Thus, there is a need for a comprehensive analysis of this largely overlooked research area of stakeholders' satisfaction and its linkage to CSFs and project success.

Several important factors need to be incorporated for determining the accomplishment or disappointment of developing a renewable energy project aiming at successful completion and efficient operational performance. Such objectives are the major reason in the identification process of the CSFs for the REPs and the support in an efficient circulation of capital. However, according to Chua et al. [40], CSFs can be recognized based on either practitioner's viewpoints or on quantifiable procedures. Table 1 highlights the critical success factors mentioned in earlier studies.

Scholars have acknowledged several important factors to boost project success (PS); these factors are comprised of team members, project managers, the external setting, and the organization itself [41]. Likewise, some of the other factors include the team capabilities and client involvement [42]; administrative backing; project objectives, and project resources [43]. Table 1 highlights the CSFs categories identified in earlier studies. Grounded on an extensive review of the pertinent literature, five important factor groups were recognized as CSFs for the development of REPs (1)-Communication factors (CF), (2)-Team factors (TF), (3)-Technical factors 
(Tech.F), (4)-Organizational factors (OF), and (5)-Environmental factors (EF).

\section{Hypothesized model development}

The necessary critical success factors for managing REPs can be divided in a number of ways. There are no limitations with regard to the creativity of names for the CSFs or of how to group them. After passing through these steps of a systematic process, the categories of critical success factors have been identified for REPs (the complete details are presented in Table 1.

The categories of CSFs used in this study are mostly in line with the CSFs framework discussed by Maqbool [2], Maqbool and Sudong [1], and Maqbool et al. [4] for the quantitative analysis, compared to other possible options (see Table 1). Firstly, Maqbool's [2], Maqbool and Sudong's [1] and Maqbool's et al. [4] framework presents a comprehensive and balanced list of success factors, which are comprised of communication factors (CF), team factors (TF), technical factors (Tech.F), organizational factors (OF), and environmental factors (EF). Most other categories of factors solely focus on subsets of critical success factors. Secondly, the components in each category of Maqbool's [2], Maqbool and Sudong's [1], and Maqbool's et al. [4] framework are derived from the results of empirical research. Thirdly, and most importantly, all of the informants in this study are project management practitioners in the field of the $\mathrm{RE}$ construction sector, which matches Maqbool's [2], Maqbool and Sudong's [1], and Maqbool's et al. [4] research context. Moreover, this categorization will be easily understood by the survey respondents, which are the focus of this study of the categorization of CSFs. It is easier and more acceptable for respondents to conceptualize the types of CSFs that correspond to their industry because they may not be so familiar with the technical terms of CSFs.

Based upon the foregoing research, it can be concluded that critical success factors perform an imperative role in determining the success of renewable energy projects (REPs). Nonetheless, minimal empirical research has been conducted in this area. Maqbool [2], Maqbool and Sudong [1], and Maqbool et al. [4] attempted to ascertain the important success factors in the REPs' context based upon a questionnaire survey from RE industry experts. These findings have yet to be quantitatively verified in the contexts of RE stakeholders. Importantly, most of the listed success factors are context-free and their suitability for application in different circumstances is not indicated. Hence, there is a need to refine the needed CSFs with respect to particular stakeholders with different RE project characteristics. Accordingly, the following propositions have emerged to be tested in this study;
H1: Communication factors (CF) are positively related to the project success (PS).

$\mathrm{H} 2$ : Team factors (TF) are positively related to the project success (PS).

H3: Technical factors (Tech.F) are positively related to the project success (PS).

$\mathrm{H} 4$ : Organizational factors (OF) are positively related to the project success (PS).

H5: Environmental factors (EF) are positively related to the project success (PS).

\section{Stakeholders' influence in constructing successful renewable energy projects}

In any sort of projects, particularly in renewable energy projects (REPs), numerous distinct and occasionally diverse interests must be contemplated. Representatives of such interests are referred to as the project stakeholders. A project stakeholder is a person or group of people who have a devolved interest in the project output and the environmental settings among which also the project wields [44]. In constructing a renewable energy project, for instance, the activities are largely dependent on multiple key stakeholders. Understanding all these key players' viewpoints can contribute to the conclusion of a successful project, avoiding undesirable situations [45]. Owed to having major control on project resources by key stakeholders, the stakeholder theory suggests to formulate and implement those processes, which would lead to stakeholders' satisfaction [46], and likewise ensure the long-term survival of the project firm [47-49].

Chinese project management practices are widely influenced by "relation/guanxi," which encourages strong relationships with key stakeholders of the project $[50,51]$. Project managers in China endeavor to please the client (owner) and contractor by thoroughly developing personal relation/guanxi. Therefore, it can be said that "relation/ guanxi" is the key indicator of the stakeholders' satisfaction in any project setting, including REPs. The importance of stakeholders' satisfaction has also been observed in the literature of REPs [42, 52-56].

Based upon the aforementioned debate, we hypothesize that this applied to key stakeholders, so that:

H6: Project stakeholders' satisfaction (SS) is positively related to project success (PS).

\section{Critical success factors, stakeholders' satisfaction, and project success}

Researchers have diverse opinions about the stakeholders' role in project management. Some of the authors consider it as one of the CSFs [57-59], however, others regard it as key determinants for CSFs affecting project success [60-66]. This study is also an effort to identify the stakeholders' satisfaction in the REPs. 
From a management viewpoint, all CSFs including stakeholders' satisfaction are interlinked. For instance, while considering the value co-creation approach, employees are obviously at the very essential of the whole perception, which entitles to be "employee first, customer second" [[60] , p. 207]. However, particularly in the last decade, all "stakeholders' satisfaction" has been identified as crucial to co-create value in the long term [60, 61].

According to Lester [62], the role of CSFs in project success largely depends on stakeholders' satisfaction. Belassi and Tukel [63] have also argued that the factors affecting project success are closely interlinked with each other. They present four categories of factors affecting project success, among which the stakeholders' influence, and that factor which is interlinked with each other are two of them. Pisarski and Brook [64] have found that the technical skills of the project managers are also vital for creating stakeholder relationships. Clarke [65] has studied the mega projects, which mostly have a large number of key stakeholders. Such projects are often organized in matrix structures, with managers managing multiple project teams and multiple stakeholders while having multiple communication channels, handling diverse technical aspects of the project, and providing a rich environment for organizational growth [66].

Based on the aforementioned discussion and the principles of stakeholders' theory, it could be hypothesized (see Fig. 1) that:

H6a: The effect of communication factors (CF) on project success (PS) is mediated by stakeholders' satisfaction (SS).
H6b: The effect of team factors (TF) on project success (PS) is mediated by stakeholders' satisfaction (SS).

H6c: The effect of technical factors (Tech.F) on project success (PS) is mediated by stakeholders' satisfaction (SS).

H6d: The effect of organizational factors (OF) on project success (PS) is mediated by stakeholders' satisfaction (SS).

H6e: The effect of environmental factors (EF) on project success (PS) is mediated by stakeholders' satisfaction (SS).

\section{Methods}

The study consists of five stages. In the first stage, from prior studies, the authors recognize the significant success factors (SSFs) that play a vital role in the REPs. The second stage of the study consists of the classification of SSFs into the five most relevant CSFs based on their specific features. The third stage is about the selection of engineering and the construction organizations operating with renewable energy projects (REPs). Moreover, for the desired survey data, information from the survey respondents is collected. The fourth stage is about two analyses, bivariate correlation analysis (BCA) and structural equation modeling (SEM). The BCA is useful to determine the significant correlation values between the variables. Similarly, SEM is helpful to understand the direct and indirect effects of CSFs on the PS. The last stage of the study examined the outcomes and suggested valuable recommendations for project management practices to the REPs development field.

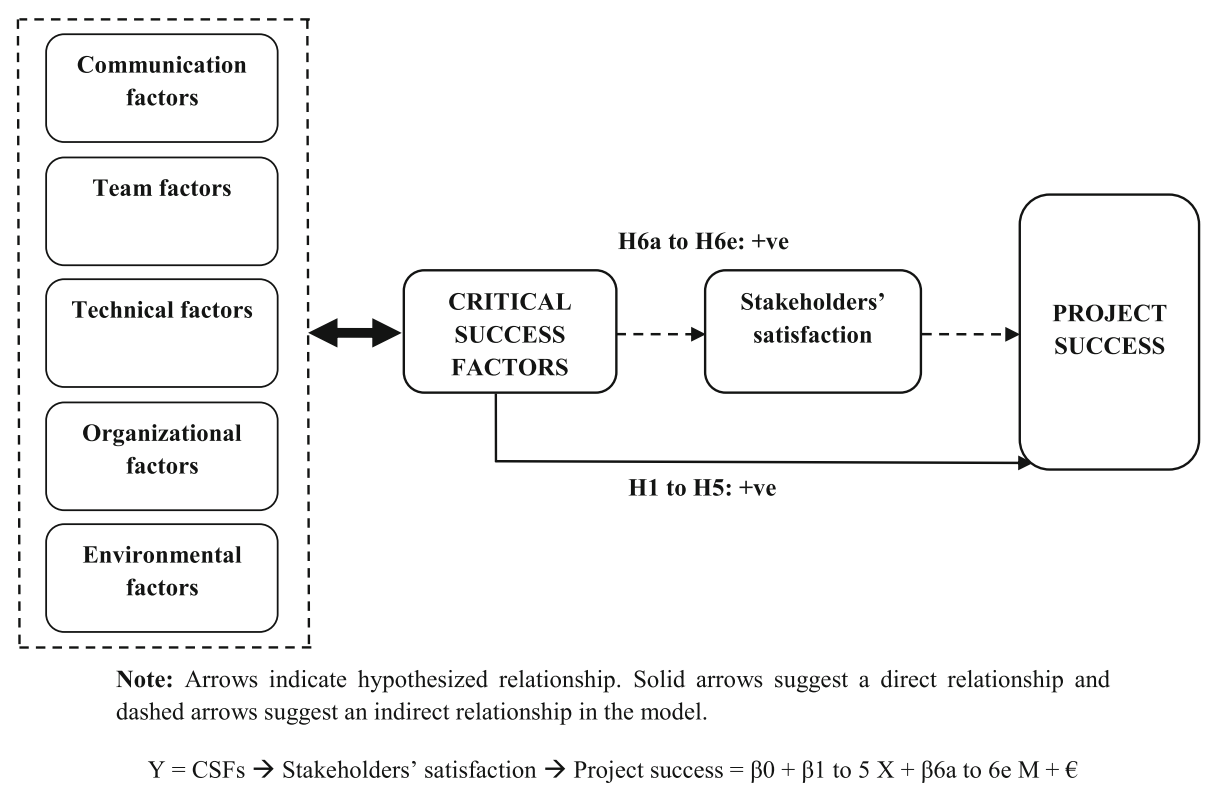

Fig. 1 Conceptual framework 


\section{Instrument development}

In this research, we used five independent variables (CF, TF, Tech.F, OF, and EF), one dependent variable (PS) and one mediating variable (SS). All the constructs' items of CSFs (mediating and independent variables) were adapted from preceding and pertinent studies. Further, the items of PS adopted by Maqbool et al. [15], a total of 57 items were used in the questionnaire along with a 5-point Likert scale (5 "strongly agree" and 1 "strongly disagree"). Then, a pilot study was performed to check the reliability and validity of the instrument. The pilot study respondents suggested some modifications in the questionnaire. Thus, the questionnaire was revised according to the recommended feedback from pilot study respondents. The revised questionnaire was circulated for the collection of survey responses.

\section{Variables and measures \\ Communication factors}

The items of communication factors are adopted from Prabhakar [41], Li [67], and Sudhakar [68]. The measurement approach incorporated 7 dimensions; i.e., leadership, reduced ambiguity, communication, balance flexibility and rigidity, maximized stability, the relationship between client and project leadership, and cooperation. A total of 11 items were used for communication factors with a 5-point Likert scale (5 "strongly agree" and 1"strongly disagree"). The Cronbach's alpha value of communication factors was 0.887 (see Table 4).

\section{Team factors}

The items of team factors are adopted from previous studies. The measurement approach incorporated six dimensions; i.e., teamwork, task orientation, team competence, team empowerment, choosing the right project team, and team commitment $[41,68]$. For the measurement of team factors, 8 items were used with a 5-point Likert scale ( 5 "strongly agree" and 1 "strongly disagree"). The Cronbach's alpha value of team factors was 0.829 (see Table 4).

\section{Technical factors}

The technical factors used 9 items developed by Prabhakar [41] and Sudhakar [68]. The technical factors consisted of 8 diverse dimensions. These dimensions include the tasks of quality testing, troubleshooting, removing legacy systems, technical implementations, technical tasks, and technology support, and technical uncertainty. All items were designed with a 5-point Likert scale (5 "strongly agree" and 1 "strongly disagree"). The Cronbach's alpha of technical factors was 0.821 (see Table 4).

\section{Organizational factors}

The organizational factors used 11 items developed by Sudhakar [68], which include realistic expectations, power, personnel recruitment, top management support, attrition, organizational politics, business process reengineering, market intelligence, reduction in cost base, personnel recruitment, and enhancement in efficiency. All the items were designed with a five-point Likert scale (5 "strongly agree" and 1"strongly disagree"). The Cronbach's alpha value of organizational factors (OF) was 0.757 (see Table 4).

\section{Environmental factors}

The environmental factors used 9 items developed by Zhao et al. [18], Sudhakar [68], and Fang and Zeng [69]. This measurement approach incorporated 8 dimensions, i.e., legal environment, political stability, credit management system, policy of paying foreign currencies, continuity of policies, domestic capital markets and credit rating, community involvement, and domestic interest rate. All items were designed with a five-point Likert scale (5 "strongly agree" and 1"strongly disagree"). The Cronbach's alpha value of environmental factors was 0.893 (see Table 4).

\section{Stakeholders' satisfaction}

Stakeholders' satisfaction was measured by means of earlier developed and used scales [70-72]. The total of 4 items for measuring the scale was adopted from Mazur and Pisarski [70], Fisher et al. [71] and Abdel-Halim's [72]. The scale was rated on a five-point Likert scale (1"strongly disagree" and 5 "strongly agree"). The Cronbach's alpha value was found to be 0.889 for SS (see Table 4).

\section{Project success (PS)}

The PS was adopted by Maqbool et al. [15]. A total of 9 items were designed with a five-point Likert Scale (5 "strongly agree" and 1"strongly disagree"). The measurement approach incorporated four dimensions, i.e., budgeted cost, scheduled time, stakeholder's satisfaction, and desired quality. The Cronbach's alpha value of project success was found to be 0.905 (see Table 4).

\section{Control variables}

In this study, the authors considered three control variables, i.e., age, gender, and education, as these aspects have been regularly connected with project success and stakeholders' satisfaction. The $t$ test and ANOVA were carried out to measure whether gender, age, and education have an influence on project success and stakeholders' satisfaction. Thus, the results confirmed that there is no effect on project success or stakeholders' satisfaction. 
Table 2 Respondents' demographic

\begin{tabular}{llll}
\hline Characteristics & Category & Frequency & Percentage \\
\hline Gender & Male & 218 & $80.15 \%$ \\
Educational background & Female & 54 & $19.85 \%$ \\
& PhD/Master & 77 & $28.31 \%$ \\
& Bachelor & 132 & $48.53 \%$ \\
Experience & < Bachelor & 63 & $23.16 \%$ \\
& $>15$ years & 133 & $48.90 \%$ \\
Designation & 10-15 years & 108 & $39.71 \%$ \\
& 5-10years & 31 & $11.39 \%$ \\
& Project director & 36 & $13.24 \%$ \\
& Project manager & 95 & $34.93 \%$ \\
& Functional manager & 79 & $29.04 \%$ \\
& Team leader & 52 & $19.12 \%$ \\
& Other & 10 & $3.68 \%$ \\
\hline
\end{tabular}

\section{Target population and survey procedure}

The target population of this study was project members, including project directors, project managers, functional managers, and team leaders from different construction organizations operating with renewable energy projects (REPs) in different areas of Pakistan. Survey respondents of current research did not carry experience of any specific project; instead, they responded vis-à-vis their own knowledge and experiences of REPs. During instrument designing, a pilot study was performed. The respondents of the pilot study were aware of the topic of this research. The respondents of the pilot study numbered 20 (project members including project managers and supporting staff). The authors personally visited construction organizations and RE project sites. They distributed 450 questionnaires among the targeted population and received 277 filled questionnaires, among them 5 were still incomplete. Thus, the completed sample size of the research was 272 and the overall response rate was $60.44 \%$. The details of the demographics of this study are presented in Table 2.

\section{Results analysis and discussion Data analysis}

We used SPSS-20 for analysis as well as the findings, respondents' demographics, reliability, descriptive statistics, and correlations. In addition, particularly for regression and mediation analysis, we employed structural equation modeling (SEM), using AMOS-18, to confirm the hypotheses. In SEM, we employed much from previous literature of project management to link the solved management problems of construction projects with other engineering projects [2, 4].

\section{Data evaluation}

Prior to initiating the data analysis phase, the survey responses were thoroughly examined for outliers, missing values, normality, and multi-collinearity. No outliers were detected in the entire data, because all the response values were found to be within the ranges (as of Q1 -1.5 IQR, Q3 + 1.5 IQR). Tabachnick and Fidell [73] suggested that for the missing data three methods, i.e., "imputation, list-wise deletion, and pairwise deletion" might be used. In this study, we adopted the "imputation" method to prevent useful data loss. Only 1 or 2 missing values were observed in the whole survey data. Moreover, the non-normality of data was also tested by using kurtosis and skewness. Tabachnick and Fidell [73] recommend that the standard values of normal data distribution are -2 and 2 .

\section{Descriptive evaluation}

Table 3 shows the descriptive statistics of this study. The results indicate that PS has a maximum uniformity among the items $(\alpha=0.902)$. Thus, it can be run as a single index-the mean value $(M=4.31, \mathrm{SD}=1.03)$ demonstrating that the PS is a significant concern for the stakeholder. However, PS will be effective if stakeholders do synergy work as a team with common goals and develop procedures for mutual problem solving [74]. Table 3 demonstrates that the values of the intervening variable are within a range of $(\alpha=0.8886, M=$ $4.19, \mathrm{SD}=1.01$ ) for stakeholders' satisfaction (SS). Moreover, Table 3 also indicates that the independent variables are in acceptable ranges, respectively CF $(\alpha=$ $0.887, M=4.20, \mathrm{SD}=1.04)$, TF $(\alpha=0.829, M=4.025$, $\mathrm{SD}=1.16)$, Tech.F $(\alpha=0.821, M=3.87, \mathrm{SD}=1.37)$, $\mathrm{OF}$ $(\alpha=0.757, M=4.04, \mathrm{SD}=1.02)$, and $\mathrm{EF}(\alpha=0.893, M$ $=4.18, \mathrm{SD}=1.067)$.

Hence, it is observed that the values of all constructs are found to be higher than the projected standard value of the reliability scales. Therefore, composites can be measured by taking an average of the particular scale's items. Further, the skewness and kurtosis values are observed to be higher than the projected standard value. Thus, the data is relatively normal.

\section{Validity of the construct}

To assess the validity of all the variables, an exploratory factor analysis (EFA) was conducted through the principal components analysis (PCA) technique. Factor analysis of the consortium of all the constructs was measured via Varimax rotation. Table 4 indicates that all variables factor loadings were higher than 0.70 or 0.50 (standard value), i.e., they are significant. The variable items, which were less than 0.50 , were removed from the final analyses to guarantee the convergent validity of the scales [75]. In addition, the factors having eigenvalues 
Table 3 The descriptive statistics

\begin{tabular}{|c|c|c|c|c|c|c|}
\hline Variable & Mean & S.D & Skewness & Kurtosis & Cronbach's a & Items \\
\hline Project success (PS) & 4.3142 & 1.03563 & 0.181 & 1.029 & 0.905 & 5 \\
\hline Stakeholders' satisfaction (SS) & 4.1942 & 1.01264 & -0.224 & 0.302 & 0.886 & 4 \\
\hline Communication factors (CF) & 4.2037 & 1.04341 & -0.265 & -0.178 & 0.887 & 11 \\
\hline Team factors (TF) & 4.0256 & 1.16541 & -0.149 & -0.527 & 0.829 & 8 \\
\hline Technical factors (Tech.F) & 3.8742 & 1.36624 & -0.055 & -0.730 & 0.821 & 9 \\
\hline Organizational factors (OF) & 4.0436 & 1.02517 & -0.249 & 0.376 & 0.757 & 11 \\
\hline Environmental factors (EF) & 4.1837 & 1.06716 & -0.212 & 0.359 & 0.893 & 9 \\
\hline
\end{tabular}

higher than 1 were also removed, which were only two to three. Table 4 shows the results of the factor analysis. The results represent the factor loadings of PS (8 items) that are higher than the standard value (0.719 to 0.935$)$. The factor loading of CF (11 items) is also higher than the proposed value; only one item was less than the standard value, which was removed from the final analyses. Table 4 depicts the value of CF (0.762 to 0.902). The outcome also indicates the factor loadings of TF ( 8 items) as higher than the standard value (0.686 to 0.905 ). The factor loading of Tech.F (7 items) amounts to 0.491 to 0.897 . Only two items were removed because the value of these items was less than the standard value. The factor loadings of $\mathrm{OF}$ and $\mathrm{EF}$ are higher than the standard value 0.696 to 0.909 and 0.719 to 0.930 , respectively. Finally, the factor loadings of the mediating variable stakeholders' satisfaction ( 4 items) are higher than the proposed standard value of 0.708 to 0.924 .

\section{Confirmatory factor analysis}

Confirmatory factor analysis (CFA) is a method of inference collection from the data and is associated with structural equation modeling (SEM). In this paper, the model is measured by confirmatory factor analysis (CFA) using the SPSS statistical software [76]. The model enhancement was active for improvement appropriate to the proposed levels. We exclude some items, and numerous trails were performed to reach the proposed scale levels. As recommended by Hair et al. [75], the ideal value for data reliability is more than 0.7 . Thus, all the constructs were measured according to a standard value. The results indicate that the factor loadings of all the items were greater than 0.5 , which is well in line with the suggestions of Fornell and Larcker [77], and is also measured at a 5\% significant level (see Table 4). Moreover, passable convergent validity was confirmed for all the constructs. Discriminant validity determined the unique measuring concepts, so all the constructs were measured compared to the discriminant validity [75]. Firstly, the outcomes of each group of the variable were paired with the outcomes of another group. Then, each model was analyzed twice as suggested by $\mathrm{Li}$ and Cavusgil [78]. The model was analyzed again by performing the correlations between two variables to unity and a second time by excluding this condition.

In this way, the discriminant validity of the constructs was measured for the specified data results. Table 5 shows the CFA and final model fitness indicators.

The validity of the dimensions was determined by construct validity [79]. However, the validity of constructs was measured by employing factor analysis. According to Malhotra [80], the ideal standard value of $\mathrm{KMO}$ (Kasier Meyer Olkin) is from 0.5 to 1.0. The KMO value of the data amounted to (0.5 to 1.0) according to the standard value. Additionally, statistical assessment for the Bartlett test of sphericity was found significant at $p=$ 0.000 and d.f. $=93$ for the correlations of all the variables as expressed in the correlation matrix, Table 6 [[81] , p. 159]. The outcomes of principal components analysis (PCA) and varimax rotation analysis confirmed

Table 4 Findings of factor analysis

\begin{tabular}{lllll}
\hline Factor & Items & Factor loading & \% of variance explained & Eigenvalue \\
\hline Project success (PS) & 5 & $0.719-0.935$ & 79.14 & 6.41 \\
Stakeholders' satisfaction (SS) & 4 & $0.708-0.924$ & 77.60 & 5.67 \\
Communication factors (CF) & 11 & $0.762-0.902$ & 84.45 & 5.35 \\
Team factors (TF) & 8 & $0.686-0.905$ & 72.40 & 4.51 \\
Technical factors (Tech.F) & 9 & $0.591-0.897$ & 67.76 & 3.94 \\
Organizational factors (OF) & 11 & $0.696-0.909$ & 73.17 & 3.70 \\
Environmental factors (EF) & 9 & $0.719-0.930$ & 75.04 & 4.58 \\
\hline
\end{tabular}


Table 5 CFA and the final model GOF indicators

\begin{tabular}{lllllll}
\hline Model & CMIN/DF & $P$ Value & TLI & GFI & CFI & RMSEA \\
\hline CFA model & 2.73 & 0.00 & 0.97 & 0.93 & 0.83 & 0.095 \\
Final model & 2.69 & 0.00 & 0.98 & 0.94 & 0.91 & 0.0092 \\
Threshold & 1.00 to 3.00 & $\geq 0.9$ & $\geq 0.9$ & $\geq 0.9$ & $\geq 0.9$ & $\leq 0.1$ \\
\hline
\end{tabular}

the eigenvalues of all the study constructs to be higher than a level of 1 . The factor loadings of the study constructs are higher than 0.50. Each specific measuring construct was loaded collectively, and the outcomes specify that the factor loading was above a 0.5 level. Thus, the findings show that the convergent validity is higher in the examined measurement scales. Moreover, the results confirmed a discriminant validity, where the items were not cross loading and rather slightly supported the particular constructs, because all the items were allotted according to the diverse constructs. The results of $\mathrm{R}$ square and average variance extracted (AVE) are highlighted in Table 6.

\section{Correlation analysis}

Table 7 shows the bivariate correlations among the independent, mediating, and dependent variables. All variables are significant $(p<0.05)$ and correlated with each other except correlations between Tech.F and CF $(\gamma=0.094, p>0.05)$. Therefore, no problem appeared in the correlation among the independent, mediating, and dependent variables.

\section{Hypothesis testing and discussion}

At the time of data analysis, there was not any kind of a multi-co-linearity problem in the variables. It was noticed that the maximum co-relations existed between CF and PS. The correlation value between CF and PS was 0.552. All the factors were significantly and positively correlated with each other, except Tech.F and CF. In this study, we investigated the relationship between CF, Tech.F, EF, TF, and stakeholders' satisfaction (SS) and their collective impact on the project success. Moreover, stakeholders' satisfaction (SS) mediates between the abovementioned five

Table 6 Results of $R^{2}$ and average variance extracted (AVE)

\begin{tabular}{lll}
\hline Factor & R-square & AVE \\
\hline Project success (PS) & 0.924 & 0.761 \\
Stakeholders' satisfaction (SS) & 0.784 & 0.686 \\
Communication factors (CF) & 0.875 & 0.462 \\
Team factors (TF) & 0.932 & 0.756 \\
Technical factors (Tech.F) & 0.794 & 0.590 \\
Organizational factors (OF) & 0.816 & 0.621 \\
Environmental factors (EF) & 0.911 & 0.719 \\
\hline
\end{tabular}

factors and the project success. Prior literature advocates that there is a significant and positive linkage between productive communication and strengthening in technical capabilities, steady usage of an organizational factor, and an external setting of the organization [82-84]. The findings highlight that the outcomes of the structural equation modeling confirmed by the direct relationship that all hypotheses are significant with the PS. Table 8 demonstrates that the hypotheses $\mathrm{H} 1, \mathrm{H} 2, \mathrm{H} 3, \mathrm{H} 4$, and $\mathrm{H} 5$ are supported. Jugdev and Mathur [85] explain in their study that communication is the main reason for the successful completion of any project. Thus, this study is a fine contribution in the context of the construction project industry in Pakistan. Some prior studies confirm that PS is transferred at the international level through technical, organizational, environmental, and team factors [86-89]. This study could be beneficial for Pakistani renewable energy projects (REPs) if one employs these five factors in the construction organization. Moreover, during the realization of renewable energy projects (REPs) were these five factors to be considered as a stockholder, the performance of construction organizations would improve. The path analysis and final SEM of the interrelationship framework is presented in Fig. 2. Path analysis is a good way to present the pictorial view of the hypothesized relationships among the variables.

The SS mediates association among CSFs and PS, as shown in Table 7, hence hypotheses $6 a, 6 b, 6 c, 6 d$, and $6 e$ were supported. After the addition of the mediation effect, the direct relation between CSFs and PS was significantly reduced, however, still over 0 , which indicates the role of partial mediation. The outcome confirms that through mediation (SS), the CSFs increase the PS. Hence, stakeholders' satisfaction of the renewable project improves the PS. The organizations occupied with renewable energy projects (REPs) should apply emphasis on the SS because the SS plays a vital role in the completion of the projects. The findings of this study recommend that stakeholders' satisfaction does in fact reduce the time and cost of a project as well as increase the product quality of the project. All in all, such factors enhance the project success. The reason behind failed projects is poor stakeholders' satisfaction. Thus, we might conclude that if renewable energy projects (REPs) want to achieve the long-term benefits of the organization, then these organizations should focus on the short-term gains. Short-term gains are generally related to winning the confidence of key stakeholders, so that it might become a continuous relationship in the form of mutual successful future renewable energy projects (REPs) as a long-term gain for project organization. Table 8 indicates the regression weights of structural equation modeling.

Holland and Light [90] and Shenhar et al. [91] argue in their study that CF enhances the success of the 
Table 7 Correlation analysis

\begin{tabular}{|c|c|c|c|c|c|c|c|}
\hline \multirow[t]{2}{*}{ Variable } & \multicolumn{7}{|c|}{ Correlation } \\
\hline & 1 & 2 & 3 & 4 & 5 & 6 & 7 \\
\hline 1 Project success (PS) & 1 & & & & & & \\
\hline 2 Stakeholders' satisfaction (SS) & $0.472^{* *}$ & 1 & & & & & \\
\hline 3 Communication factors (CF) & $0.552^{* *}$ & $0.405^{* *}$ & 1 & & & & \\
\hline 4 Team factors (TF) & $0.517^{* *}$ & $0.374^{* *}$ & $0.365^{* *}$ & 1 & & & \\
\hline 5 Technical factors (Tech.F) & $0.226^{* *}$ & $0.242^{* *}$ & 0.094 & $0.156^{*}$ & 1 & & \\
\hline 6 Organizational factors (OF) & $0.242^{*}$ & $0.234^{* *}$ & $0.196^{*}$ & $0.274^{* *}$ & $0.214^{* *}$ & 1 & \\
\hline 7 Environmental factors (EF) & $0.398^{*}$ & $0.356^{*}$ & $0.366^{* *}$ & $0.418^{* *}$ & $0.316^{* *}$ & $0.425^{* *}$ & 1 \\
\hline
\end{tabular}

**Correlation at $\leq 0.01$ level

*Correlation at $\leq 0.05$ level

Table 8 Regression weights

\begin{tabular}{llll}
\hline Hypothesis & Estimate & S.E. & C.R.
\end{tabular}

\section{Hypothesis 1}

Project Success (PS) <--- Communication-Factors (CF)

Hypothesis 2

Project Success (PS) $<---$ Team-Factors (TF)

Hypothesis 3

Project Success (PS) $<---$ Technical-Factors (Tech.F)

Hypothesis 4

Project Success (PS) <--- Organizational-Factors (OF)

\section{Hypothesis 5}

Project Success (PS) < --- Environmental-Factors (EF)

\section{Hypothesis 6}

Project Success (PS) < --- Stakeholders'-Satisfaction (SS)

\section{Hypothesis $6 a$}

Stakeholders' Satisfaction (SS) <---Communication-Factors (CF)

Project Success (PS) < --- Communication-Factors (CF)

Project Success (PS) < --- Stakeholders'-Satisfaction (SS)

\section{Hypothesis 6b}

Stakeholders' Satisfaction (SS) <--- Team-Factors (TF)

Project Success (PS) $<---$ Team-Factors (TF)

Project Success (PS) $<---$ Stakeholders'-Satisfaction (SS)

\section{Hypothesis $6 c$}

Stakeholders' Satisfaction (SS) $<---$ Technical-Factors (Tech.F)

Project Success (PS) <--- Technical-Factors (Tech.F)

Project Success (PS) $<---$ Stakeholders'-Satisfaction (SS)

\section{Hypothesis 6d}

Stakeholders' Satisfaction (SS) < --- Organizational-Factors (OF)

Project Success (PS) <--- Organizational-Factors (OF)

Project Success (PS) <--- Stakeholders'-Satisfaction (SS)

\section{Hypothesis 6e}

Stakeholders' Satisfaction (SS) < --- Environmental-Factors (EF)

Project Success (PS) < --- Environmental-Factors (EF)

Project Success (PS) $<---$ Stakeholders'-Satisfaction (SS)
0.198

0.046

4.657

1.069

0.147

7.491

0.136

0.046

2.725

0.171

0.049

3.684

0.514

0.086

5.871

0.506

0.360

0.119

0.462

0.890

0.324

0.363

0.828

0.168

0.094

0.768

0.078

0.168

0.794

0.070

0.149
0.064

3.424

0.032

0.024

0.068

0.827

4.028

5.016

0.076

0.025

10.124

0.643

0.082

0.864

0.060

10.022

0.014

1.629

0.025

0.746

0.068

9.604

0.026

0.632

0.020

3.152

0.060

10.132

0.023

0.689

0.015
*** 


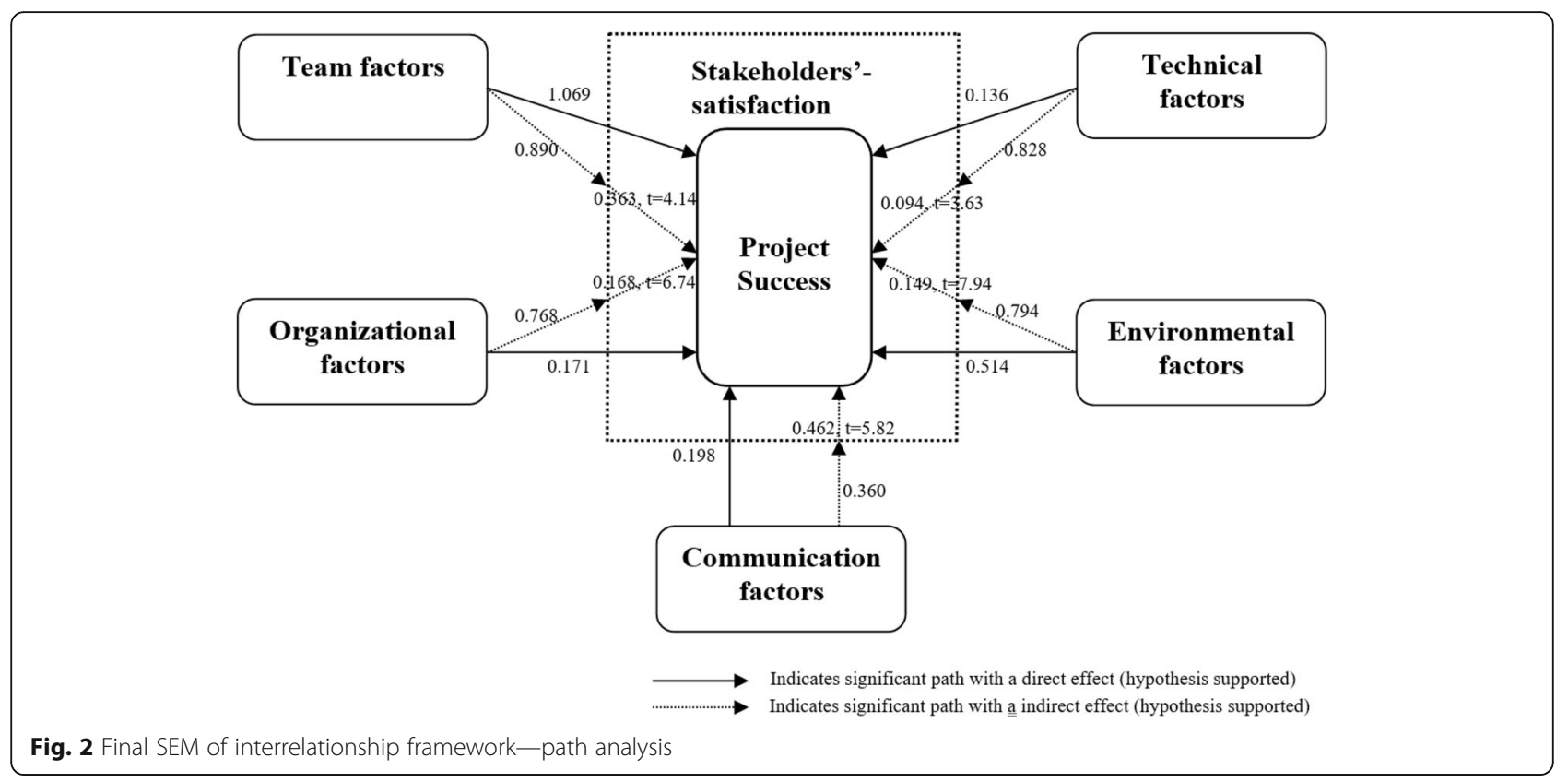

projects. In the current research, the relationship between CF and PS of the construction industry of Pakistan was tested. The results confirm that in the context of Pakistan the above relationship is correct. Likewise, internal and external settings of the construction firms derived as a key factor for the completion of the ultimate outcome and the process of project management. Similarly, Wüste and Schmuck [92] and Rajkumar [93] claimed that the EF effected the PS. The outcomes are exceptional in the setting of Pakistan due to the organizational culture of the results, which is unique [94]. The failing percentage of renewable energy projects (REPs) on an international scale is shocking, and the findings of the current study would support the policymakers in framing constructive plans aimed at attaining maximum stakeholders' satisfaction.

This research was initiated by asking the important question that, in spite of the tremendous progress in project management, very little is known about the influential connection between CSFs and REPs in encircling PS at a level that satisfies all the major partners. The primary objective of this research was to recognize CSFs, and introduce and approve a framework grounded on hypothetical ideas that openly instigates the interpretation of project stakeholders' aims in order to act aggressively for a high performing renewable energy (RE) project, while simultaneously assessing the apparent success level and acceptance in well-defined stakeholders' satisfaction (SS) contexts. However, through the SEM, a positive and significant connection was found between CSFs and PS of REPs. Moreover, the mediating role of SS was also confirmed among the five categories of CSFs (CF, TF, Tech.F, OF, and EF) and PS. The findings of this study also supported the theoretical conceptualized proposed model that explains the relationship between the five CSFs and PS in renewable energy projects (REPs). Similarly, it was observed that EF is the major CSFs in determining the REPs. Moreover, the framework of this study indicated that the idea of project success is developed on the basis of CSFs, which is a novel and original contribution in the context of REPs. Finally, this research is a pioneer study that applies the impact of CSFs on the stakeholders' satisfaction in renewable energy projects (REPs). Therefore, this study will be productive for construction projects in the renewable energy industry.

The outcomes of the current research report allowed for providing a solid comprehension toward a distinguishing proof of critical success factors (CSFs) and their relationship with the achievement of the REPs. The study makes some mandatory contributions. It (1) distinguishes the significant success factors (SSFs) for REPs extends in pertinent literature; (2) classes the SSFs into five CSFs clusters; i.e., communication factors (CF), team factors (TF), technical factors (Tech.F), organizational factors (OF), and environmental factors (EF); (3) affirms a comprehensive framework that envelops the pertinent CSFs to cultivate project achievement in the form of stakeholders' satisfaction (SS), noticed as the first time in the literature of sustainable power source projects; (4) initiates the discourse and directs the route to the reelucidation of project success (PS) in the pertinent literature, as indicated by projects operational performance. Success, not exclusively to the activities yet to the association taking a shot at sustainable power source projects itself can be build up on the CSFs for those who are 
required to predict the intended outcomes in renewable energy investments.

\section{Conclusions}

In this study, our results support the linkages among CSFs and project success (PS). The empirical findings of the current research indicated that CSFs are those factors that increase the success of the REPs. Moreover, stakeholders' satisfaction (SS) as a mediating variable plays a vital role in boosting the actual success of the project in the RE industry. This study advances the debate on numerous success factors and identifies five significant CSFs, i.e., communication factor $(\mathrm{CF})$, team factors (TF), technical factors (Tech.F), organizational factors (OF), and environmental factors (EF). These five factors had been identified on the basis of some current and prior studies, as well as the survey interview with project specialists, i.e., project directors, project managers, and project team leaders of REPs. Moreover, on the basis of previous studies, the authors clearly identified stakeholders' satisfaction (SS) as a mediating variable in this study. The model and theoretical concept of this study showed that the CSFs had affected the project success (PS) by using stakeholders' satisfaction (SS) as a mediating variable, which is a novel contribution in the context of renewable energy projects (REPs). This is the first and only research, which applies the impact of CSFs on stakeholders' satisfaction (SS) and project success in REPs.

Our results confirmed the theoretical prediction that CSFs have a positive and significant effect on the success of REPs. The literature on CSFs was adequately used to demonstrate how construction organizations can efficiently use CSFs to increase project success (PS). Moreover, the proposed hypotheses have also confirmed that CSFs have a significant association with the success of REPs, and stakeholders' satisfaction (SS) mediates in the relationship between CSFs and project success (PS). Thus, the CSFs were found to be dynamical for project success (PS), where stakeholders' satisfaction (SS) being a significant component to create the connection among critical success factors (CSFs) and project success (PS). It was clearly shown that project success (PS) in renewable energy projects (REPs) can only be achieved through project stakeholders' satisfaction (SS). These empirical findings have useful implications for academicians and practitioners. This research will help projectoriented organizations in weighing the CSFs from different perspectives that have not yet been discussed. In the future, such kinds of research should be cautiously carried out at an international level and be applied to ensure performance in other relevant sustainable projects besides renewable energy projects (REPs). Likewise, the current study is based upon the project team members' perceptions with regard to the given success factors. A future research with an experimental technique should be encouraged for comparing its results with the results of the current work to better understand the CSFs in REPs.

\section{Abbreviations \\ CSFs: Critical success factors; SSFs: Significant success factors; RE: Renewable energy; REPs: Renewable energy projects; SS: Stakeholders' satisfaction; PS: Project success; CF: Communication factors; TF: Team factors; Tech.F: Technical factors; OF: Organizational factors; EF: Environmental factors; SEM: Structural equation modeling}

\section{Acknowledgements}

This study was supported by a grant from the National Natural Science Foundation of China (No.: 71872094). The writers would like to thank the support of the Foundation. The authors also appreciate financial support from the deanship of scientific research, Prince Sattam bin Abdulaziz University, Al-Khaarj, Saudi Arabia.

\section{Authors' contributions}

The authors read and approved the final manuscript.

Funding

National Natural Science Foundation of China (No.: 71872094).

\section{Availability of data and materials}

The data generated or analyzed during the study are available from the corresponding author on reasonable request.

\section{Ethics approval and consent to participate}

Ethics approval is not applicable in the study.

\section{Consent for publication}

The survey respondents of the study have given their consent for the data to be used and published in this scientific article.

\section{Competing interests}

The authors declare that they have no competing interests.

Received: 4 January 2018 Accepted: 28 June 2020

Published online: 08 August 2020

\section{References}

1. Magbool R (2018) Sudong Y (2018) Critical success factors for renewable energy projects; empirical evidence from Pakistan. Journal of Cleaner Production 195:991-1002

2. Maqbool R (2018) Efficiency and effectiveness of factors affecting renewable energy projects; an empirical perspective. Energy 158(2018):944-956

3. WCED S (1987) World commission on environment and development. Our common future 17:1-91.

4. Maqbool R, Rashid Y, Sultana S, Sudong Y (2018) Identifying the critical success factors and their relevant aspects for renewable energy projects; an empirical perspective. Journal of Civil Engineering and Management 24(3): 223-237

5. Ashfaq S, Tang Y, Maqbool R (2019) Volatility spillover impact of world oil prices on leading Asian energy exporting and importing economies' stock returns. Energy 188:116002

6. Ashfaq S, Maqbool R, Rashid Y (2020) Daily dataset of oil prices and stock prices for the top oil exporting and importing countries from the region of Asia. Data in brief 28:104871

7. Raja I. A, Abro R (1994) Solar and wind energy potential and utilization in Pakistan. Renewable Energy 5(1-4):583-586.

8. Yazdanie M, Rutherford, P (2010) Renewable energy in Pakistan: policy strengths, challenges \& the path forward. ETH Zurich.

9. Amjad M, Zafar Q, Khan F, Sheikh M (2015) Evaluation of weather research and forecasting model for the assessment of wind resource over Gharo, Pakistan. International Journal of Climatol 35(8):1821-1832

10. Khan N, Mirza I (2014) Khalil M (2014) Renewable energy in Pakistan: status and trends. Altern. Energy Dev, Board 
11. Bridgwater A (1999) Principles and practice of biomass fast pyrolysis processes for liquids. Journal of analytical and applied pyrolysis 51(1-2):3-22

12. Zaigham N, Nayyar (2010) Renewable hot dry rock geothermal energy source and its potential in Pakistan. Renewable and Sustainable Energy Reviews 14(3):1124-1129.

13. Malik S, Magbool M (2017) Energy potential of Pakistan. NFC IEFR Journal of Engineering and Scientific Research 1(1):78-86

14. Siddiqui H (2016) Failed plan, The news international August, 2016. Retrieved from https://www.thenews.com.pk/magazine/instep-today/14081 0-Failed-plan

15. Magbool R, Sudong Y, Manzoor N, Rashid Y (2017) The impact of emotional intelligence, project managers' competencies, and transformational leadership on project success. Project Management Journal 48(3):58-75 https://doi.org/10.1177/875697281704800304

16. Standish G (1994) The CHAOS Report. Boston: The Standish Group International, Inc,. Available online https://www.standishgroup.com/sample_ research_files/chaos_report_1994.pdf ().

17. Baccarini D, Collins A (2003) Critical success factors for projects, surfing the waves: management challenges; management solutions (pp. 2-5). In Proceedings of the 17th ANZAM Conference, Perth, Australia. http://ro.ecu. edu.au/ecuworks/7140

18. Zhao Z, Zuo J, Zillante G, Wang X (2010) Critical success factors for BOT electric power projects in China: thermal power versus wind power. Renewable energy 35(6):1283-1291 https://doi.org/10.1016/j.renene.2009.09.016

19. Ika L, Diallo A, Thuillier D (2012) Critical success factors for World Bank projects: an empirical investigation. International journal of project management 30(1):105-116 https://doi.org/10.1016/j.jproman.2011.03.005

20. Xu P, Chan E, Qian Q (2011) Success factors of energy performance contracting (EPC) for sustainable building energy efficiency retrofit (BEER) of hotel buildings in China. Energy Policy 39(11):7389-7398 https://doi.org/10. 1016/j.enpol.2011.09.001

21. Zhao Z (2018) Chen Y (2018) Critical factors affecting the development of renewable energy power generation: evidence from China. Journal of Cleaner Production 184:466-480

22. Kirchhoff H, Kebir N, Neumann K, Heller P (2016) Strunz K (2016) Developing mutual success factors and their application to swarm electrification: microgrids with $100 \%$ renewable energies in the Global South and Germany. Journal of Cleaner Production 128:190-200. https://doi.org/10. 1016/j.jclepro.2016.03.080

23. Liang H, Ren J, Gao Z, Gao S, Luo X, Dong L (2016) Scipioni A (2016) Identification of critical success factors for sustainable development of biofuel industry in China based on grey decision-making trial and evaluation laboratory (DEMATEL). Journal of Cleaner Production 131:500508. https://doi.org/10.1016/j.jclepro.2016.04.151

24. Zhao Z, Yan H, Zuo J, Tian Y (2013) Zillante G (2013) A critical review of factors affecting the wind power generation industry in China. Renewable and Sustainable Energy Reviews 19:499-508

25. Dong L, Liang H, Gao Z, Luo X (2016) Ren J (2016) Spatial distribution of China's renewable energy industry: regional features and implications for a harmonious development future. Renew. Sustain. Energy Rev 58:1521-1531

26. Lin B (2014) Moubarak M (2014) Renewable energy consumption-economic growth nexus for China. Renew. Sustain. Energy Rev 40:111-117

27. Young J (2017) Brans M (2017) Analysis of factors affecting a shift in a local energy system towards $100 \%$ renewable energy community. Journal of Cleaner Production 169:117-124. https://doi.org/10.1016/j.jclepro.2017.08.023

28. Carlisle J, Kane S, Solan D, Bowman M, Joe J (2015) Public attitudes regarding large-scale solar energy development in the U.S. Renew. Sustain. Energy Rev 48(2015):835-847

29. Zhao Z, Chen Y (2016) Chang R (2016) How to stimulate renewable energy power generation effectively?-China's incentive approaches and lessons. Renew. Energy 92:147-156

30. Xavier R, Komendantova N, Jarbandhan V, Nel D (2017) Participatory governance in the transformation of the South African energy sector: critical success factors for environmental leadership. Journal of Cleaner Production 154:621-632

31. Ansari M, Kharb R, Luthra S, Shimmi S (2013) Chatterii S (2013) Analysis of barriers to implement solar power installations in India using interpretive structural modeling technique. Renew. Sustain. Energy Rev 27:163-174

32. Pantaleo A, Giarola S, Bauen A (2014) Shah N (2014) Integration of biomass into urban energy systems for heat and power. Part II: sensitivity assessment of main techno-economic factors. Energy Convers. Manag 83:362-376
33. He Y, Xia T, Liu Z, Zhang T (2013) Dong Z (2013) Evaluation of the capability of accepting large-scale wind power in China. Renew. Sustain. Energy Rev 19:509-516

34. Goh H, Lee S, Chua Q, Goh K, Kok B (2014) Teo K (2014) Renewable energy project: project management, challenges and risk. Renew. Sustain. Energy Rev 38:917-932

35. Zhao X, Wang J, Liu X, Liu P (2012) China's wind, biomass and solar power generation: what the situation tells us? Renew. Sustain. Energy Rev 16(8): 6173-6182

36. Lam J, Woo C, Kahrl F (2013) Yu W (2013) What moves wind energy development in China? Show me the money! Appl. Energy 105:423-429

37. Qi T, Zhang X (2014) Karplus V (2014) The energy and CO2 emissions impact of renewable energy development in China. Energy Pol 68:60-69

38. Kaldellis J, Kapsali M, Kaldelli E (2013) Katsanou E (2013) Comparing recent views of public attitude on wind energy, photovoltaic and small hydro applications. Renew. Energy 52:197-208

39. Wu G, Zeng M, Peng L, Liu X, Li B (2016) Duan J (2016) China's new energy development: status, constraints and reforms. Renew. Sustain. Energy Rev 53:885-896

40. Chua D, Kog Y, Loh P (1999) Critical success factors for different project objectives. Journal of construction engineering and management 125(3): 142-150 https://doi.org/10.1061/(ASCE)0733-9364(1999)125:3(142

41. Prabhakar $\mathrm{G}$ (2008) Project and their management: a literature review. International Journal of Business and Management 3(9):3-10 https://doi.org/ 10.5539/ijbm.v3n8p3

42. Baker $L$ (2015) The evolving role of finance in South Africa's renewable energy sector. Geoforum 64:146-156

43. Wixom B, Watson $H$ (2001) An empirical investigation of the factors affecting data warehousing success. MIS quarterly 25(1):17-41. https://doi. org/10.2307/3250957

44. McElroy B, Mills C (2000) Managing stakeholders. In: Turner RJ, Simister SJ, editors. (2000). Gower handbook of project management. 3rd ed.. Gower publishing limited; 2000. [Chapter 42].

45. Watson T, Osborne-Brown S, Longhurst M (2002) Issues Negotiation ${ }^{\text {TM }}$ investing in stakeholders. Corporate Communications: An International Journal 7(1):54-61

46. Pfeffer J, Salancik G (2003) The external control of organizations: A resource dependence perspective. Stanford University Press

47. Freeman R (2010) Strategic management: a stakeholder approach Cambridge university press

48. Hillman A, Keim G (2001) Shareholder value, stakeholder management, and social issues: what's the bottom line? Strategic management journal 22(2):125-139

49. Post J, Preston L, Sachs S (2002) Managing the extended enterprise: the new stakeholder view. California management review 45(1):6-28

50. Tsang E (1998) Can guanxi be a source of sustained competitive advantage for doing business in China? Academy of Management Perspectives 12(2):64-73

51. Chen P, Partington D (2004) An interpretive comparison of Chinese and Western conceptions of relationships in construction project management work. International Journal of Project Management 22(5):397-406

52. Rehman A, Deyuan Z, Chandio A, Hussain I (2018) An empirical analysis of rural and urban populations' access to electricity: evidence from Pakistan. Energy, Sustainability and Society 8(1):40.

53. Dvarioniene J, Gurauskiene I, Gecevicius G, Trummer D, Selada C, Marques I, Cosmi C (2015) Stakeholders involvement for energy conscious communities: The Energy Labs experience in 10 European communities. Renewable Energy 75:512-518

54. Upreti B, van der Horst D (2004) National renewable energy policy and local opposition in the UK: the failed development of a biomass electricity plant. Biomass and bioenergy 26(1):61-69

55. Wüstenhagen $R$, Wolsink M, Bürer M (2007) Social acceptance of renewable energy innovation: an introduction to the concept. Energy policy 35(5): 2683-2691

56. Reddy S, Painuly J (2004) Diffusion of renewable energy technologies-barriers and stakeholders' perspectives. Renewable Energy 29(9):1431-1447

57. Yusof S, Aspinwall E (1999) Critical success factors for total quality management implementation in small and medium enterprises. Total Quality Management 10(4-5):803-809

58. Karuppusami G, Gandhinathan R (2006) Pareto analysis of critical success factors of total quality management: a literature review and analysis. The TQM magazine 18(4):372-385 
59. Hietschold N, Reinhardt R, Gurtner S (2014) Measuring critical success factors of TQM implementation successfully-a systematic literature review. International Journal of Production Research 52(21):6254-6272

60. Ramaswamy V, Ozcan K (2014) The co-creation paradigm. Stanford University Press, CA, p 333

61. Kharub M, Sharma R (2016) Investigating the role of CSF's for successful implementation of quality management practices in MSMEs. International Journal of System Assurance Engineering and Management 7(1):247-273

62. Lester D (1998) Critical success factors for new product development. Research-Technology Management 41(1):36-43

63. Belassi W, Tukel O (1996) A new framework for determining critical success/ failure factors in projects. International journal of project management 14(3): $141-151$

64. Pisarski A, Brook C (2013) Achieving success in the Australian mega-project environment: the role of leaders' emotional intelligence. In 2013 Emotional Intelligence in the Workplace, 29-31 May. Ashridge United Kingdom.

65. Clarke N (2010) Projects are emotional: How project managers' emotional awareness can influence decisions and behaviours in projects. International Journal of Managing Projects in Business 3(4):604-624

66. Thomas G, Fernández W (2008) Success in IT projects: a matter of definition? International journal of project management 26(7):733-742

67. Li E (1997) Perceived importance of information system success factors: a meta analysis of group differences. Information and Management 32(1):1528 https://doi.org/10.1016/S0378-7206(97)00005-0

68. Sudhakar G (2012) A model of critical success factors for software projects. Journal of Enterprise Information Management 25(6):537-558 https://doi. org/10.1108/17410391211272829

69. Fang $Y$, Zeng $Y$ (2007) Balancing energy and environment: the effect and perspective of management instruments in China. Energy 32(12):2247-2261 https://doi.org/10.1016/j.energy.2007.07.016

70. Mazur A, Pisarski A (2013) The ISR and ESR scales: measures of the project manager-stakeholder relationship. 2013 British Academy of Management, 10-12 September, Liverpool, United Kingdom.

71. Fisher R, Maltz E, Jaworski B (1997) Enhancing communication between marketing and engineering: the moderating role of relative functional identification. J. Mark 61(3):54-70

72. Abdel-Halim A (1981) A re-examination of ability as a moderator of role perceptions-satisfaction relationships. Pers. Psychol 34(3):549-561

73. Tabachnick B, Fidell L (2012) Using multivariate statistics, 6th ed.; Pearson: New Jersey, USA: 2012; pp. 67-80, ISBN. 0205849571,9780205849574

74. Larson E (1995) Project partnering: results of study of 280 construction projects. Journal of management in engineering 11(2):30-35 https://doi.org/ 10.1061/(ASCE)0742-597X(1995)11:2(30

75. Hair J, Black W, Babin B, Anderson R, Tatham R (2006) Multivariate data analysis (Vol. 6): Pearson Prentice Hall Upper Saddle River. New Jersey, USA; pp. 295-375, ISBN. 0130329290, 9780130329295.

76. Andertson J, Gerbing D (1998) Structural equation modeling in practice: a review and recommended two-step approach. Psychological Bulletin 103(2): 411-423 https://doi.org/10.1037/0033-2909.103.3.411

77. Fornell C, Larcker D (1981) Evaluating structural equation models with unobservable variables and measurement error. Journal of Marketing Research 18(1):39-50. https://doi.org/10.2307/3151312

78. Li T, Cavusgil T (2000) Decomposing the effects of market knowledge competence in new product export. European Journal of Marketing 34(1): 57-80 https://doi.org/10.1108/03090560010306205

79. Cavana R, Delahaye B, Sekaran U (2001) Applied business research: qualitative and quantitative methods, 1st ed. John Wiley \& Sons Australia. Milton, Queensland, Australia; pp. 174-216, ISBN. 0471341266, 9780471341260.

80. Malhotra N (2008) Marketing research: an applied orientation, $\left(5^{\text {th }}\right.$ ed). Pearson Education: New Jersey, USA; pp. 600-720, ISBN. 8131723178 , 9788131723173.

81. Kwek C, Lau T, Tan H (2010) Education quality process model and its influence on students' perceived service quality. International Journal of Business and Management 5(8):154-165

82. Allen T (2000) Architecture and communication among product development engineers. In Engineering Management Society, 2000. Proceedings of the 2000 IEEE (pp. 153-158). Albuquerque, NM, USA, 15-15 August 2000; IEEE. Print ISBN: 0-7803-6442-2. https://doi.org/10.1109/EMS. 2000.872493

83. Olasupo A, Ibrahim O, Gazal H (2012) Effect of project management on project success, Australian Journal of Business and Management Research
2(3):1-11. Available online https://scholar.google.com/scholar?hl=en\&as_sdt= $0 \% 2 C 5 \& q=E f f e c t+o f+$ Project+Management+on+Project+Success.\&btnG= (accessed on 04 December 2017)

84. Varona F (1996) Relationship between communication satisfaction and organizational commitment in three Gautemalan organizations. International Journal of Business Communication 33(2):111-140 https://doi. org/10.1177/002194369603300203

85. Jugdev K, Mathur G (2012) Classifying project management resources by complexity and leverage. International Journal of Managing Projects in Business 5(1):105-124 https://doi.org/10.1108/17538371211192928

86. Buchanan D, Badham R (2008) Power, politics, and organizational change: winning the turf game. London, 1st ed. UK: SAGE Publications. pp. 173-286, ISBN. 1412928338, 9781412928335.

87. Kamal M (2006) IT innovation adoption in the government sector: identifying the critical success factors. Journal of Enterprise Information Management 19(2):192-222 https://doi.org/10.1108/17410390610645085

88. Young R, Poon S (2013) Top management support-almost always necessary and sometimes sufficient for success: findings from a fuzzy set analysis. International Journal of Project Management 31(7):943-957 https://doi.org/10.1016/j.jproman.2012.11.013

89. Globerson S, Zwikael O (2002) The impact of the project manager on project management planning processes. Project management journal 33(3):58-64

90. Holland C, Light B (1999) A critical success factors model For ERP implementation. IEEE Software 16(3):30-36. https://doi.org/10.1109/52. 765784

91. Shenhar A, Levy O, Dvir B (1997) Mapping the dimensions of project success. Project Management Journal, 28(2), 5-13. Available online https://scholar.google.com.sg/scholar?hl=en\&as_sdt=0\%2C5\&q=Mapping+ the+dimensions+of+project+Success\&btnG $=($ ).

92. Wüste A, Schmuck P (2012) Bioenergy villages and regions in Germany: an interview study with initiators of communal bioenergy projects on the success factors for restructuring the energy supply of the community. Sustainability 4(2):244-256. https://doi.org/10.3390/su4020244

93. Rajkumar S (2010) Art of communication in project management. Paper presented at $\mathrm{PMI}^{\oplus}$ Research Conference: Defining the Future of Project Management, Washington, DC. Newtown Square, PA: Project Management Institute. Retrieved from https://www.pmi.org/learning/library/effectivecommunication-better-project-management-6480

94. Maqbool R, Deng X (2020) Ashfaq S (2020) Success of renewable energy projects under the financial and non-financial performance measures. Sustainable Development. https://doi.org/10.1002/sd.2089

\section{Publisher's Note}

Springer Nature remains neutral with regard to jurisdictional claims in published maps and institutional affiliations.
Ready to submit your research? Choose BMC and benefit from:
- fast, convenient online submission
- thorough peer review by experienced researchers in your field
- rapid publication on acceptance
- support for research data, including large and complex data types
- gold Open Access which fosters wider collaboration and increased citations
- maximum visibility for your research: over $100 \mathrm{M}$ website views per year
At BMC, research is always in progress.
Learn more biomedcentral.com/submissions 